\title{
Vulvar Basaloid Carcinoma
}

National Cancer Institute

\section{Source}

National Cancer Institute. Vulvar Basaloid Carcinoma. NCI Thesaurus. Code C40286.

A squamous cell carcinoma that arises from the vulva and is characterized by the presence of nests of malignant basaloid cells with a scant amount of cytoplasm. 